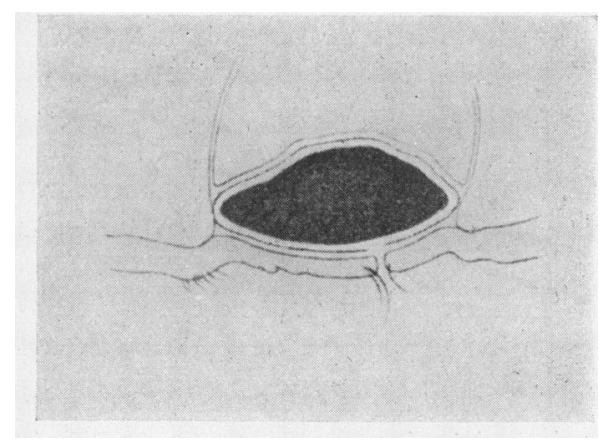

FIG. 3.

Transsection of the mould.

be in the eyelid-fissure. When 8-10 days have lapsed, the mould is finally removed.

The method satisfies all the claims of a plastic-operation. We can adapt it to any case in any circumstance and it can be performed simply in a short time.

\title{
LITERATURE
}

Esser.-Zentralbl. $f$. d. ges. Ophthal., Vol. XXXVI.

Zentralbl.f. d. ges. Ophthal., Vol. XXXV.

CsAPODY.-Zeitschr. $f$. Augenheilk., Vol. LXXXVII.

Zeitschr. f. Augenheilk., Vol. XCIV.

Blaskovics-Kreiker.-Eingriffe am Auge. Ferd. Enke, Stuttgart, 1938.

\section{A CASE OF PRIMARY LUES IN THE SUPERIOR FORNIX*}

\section{BY}

IDA CZUKRÁSZ, M.D.

(FROM THE UNIVERSITY EYE CLINIC, DEBRECEN, UNDER THE CHARGE OF PROFESSOR A. KREIKER)

I HERE wish to give a report on a forty year old physician, who called at the clinic on February 8th, 1938.

On January 2nd this year, as he told us, one of his patients who was suffering from plaques muqueses coughed into his right eye. A week-or so before, that is to say four weeks after the occurrence, his right eye became swollen, the conjunctiva red and the preauricular lymph glands infiltrated. No compresses or any astringent material helped, so he thought of luetic infection.

\footnotetext{
* Read before the Hungarian Ophthalmological Society, October 2, 1938.
} 
Clinical Notes.-Vision of the right eye $1 / 2$, no glass can correct because of lacrimation; left eye $0.5 \mathrm{D}$.cyl.-1.5 D. sph. Axis $180^{\circ}=1$. Right eye-lids are bloated, conjunctiva red, and some follicles of various sizes can be seen in the superior fornix with a slight papillary hypertrophy on the tarsal part. The eye shows nothing else. Preauricular lymph glands are swollen and painful. No bacteria or inclusion-bodies can be seen in the smear. Wassermann reaction negative.

The conjunctiva all through, but especially in the superior and inferior fornices, shows a diffuse oedema. Nowhere can an induration, ulcer or abrasion be found. That is to say, no suspicious place through which the luetic infection could have penetrated. In such an uncertain situation we did not dare to start with an antiluetic treatment. Perhaps we could have left the patient for ever unaware that it was syphilis. There was no spot from which we could have taken "Reitzserum " for spirochaeta-test on the conjunctiva.

Consequently we made in general the diagnosis of epitheliosis. Heteroprotein injections, resorcin drops were advised with the remark that if it does not improve, further examination and clinical treatment will be necessary.

On February 20th he came back. No improvement, but the state became worse because of difficulty with eversion of the fornix. There was not any circumscribed induration present. Cornea was stippled. Swelling of lymph glands heightened, even the submaxillary glands became the size of an egg. Temperature, normal.

Laboratory Notes.-Erythrocytes : 4,960,000; leucocytes : 8,300, with the qualitative blood-test a slight lymphocytosis was found. Bacterial cultures again negative. Bang complement, negative, in self complement, which shows the general reaction, no haemolysis in $0.15 \mathrm{c} . \mathrm{cm}$.

Wassermann reaction $:++++$.

Based on this and regarding the induration of regional glands we had now to admit that a primary lues was present on the conjunctiva. Verification of our diagnosis arrived, when after the 5 th neosalvarsan injection the conjunctival appearance changed and at the end of the first antiluetic treatment the eye healed entirely, without any scars.

The eye, as Münchheimer's statistics say, takes the 7 th place in the list of extragenital infections. It appears mostly on the skin of the eye-lid, now and then on the lid-margin as a chancre, and sometimes the infiltration extends to the tarsal conjunctiva. Specially rarely can we meet the primary affection on the conjunctiva. There is a certain succession in the occurrence: lower fornix, bulbar conjunctiva, upper fornix. 
However, the conjunctival appearance is various. Simple conjunctivitis, lymphomatosis up to exulcerated chancre, all variations of conjunctival disease have been described.

It is curious, but none of the symptoms is characteristic of luetic infection. Swollen conjunctiva, follicles, papillary hypertrophy (as in our case), yellowish-red oily induration can be of various infectious consequence: of trachoma, tularaemia as well as of atypical primary affection.

We are likely to make the diagnosis of epitheliosis or lymphomytosis conjunctivae, the more so if only one eye is affected. Not even the regional glands can clear up the situation, because quite often they are painful.

Positive argument for the primary affection is only the spirochaeta pallida. If none can be found, Wassermann reaction and the result of antiluetic treatment is the proof.

The fact that the spirochaeta-infection has no special symptoms on the conjunctiva, caused our first mistake, and probably in many described cases.

It seems to us, and that is why we report this case, that the skin and genitals react with a special induration to the spirochaetainvasion. That is quite natural, if we take the difference between conjunctiva and all the rest of the organs and tissues. What we saw in the above described case, did not indicate lues until we got the blood-test.

It seems to us that the spirochaetes can penetrate the loose epithelium of the conjunctiva even if there is no lesion. Conditions in the loose subconjunctival tissue do not seem suitable for the primary defence which involves the first organic reaction, the primary sclerosis on the genitals. Immediately, as the spirochaetes pass through the conjunctiva they arrive in an abundant lymphatic stream and the first settlement will be the regional lymph glands. That is why the regional bubo so quickly developed, and it was painful because of the rapid growth and it was not indolent as specific for lues. Properly speaking we might suppose that in this case the primary sclerosis is in the preauricular gland.

How much it is to be regretted that all these are not known or not enough known. The opinion that the spirochaete produces a specific reaction, no matter where the infective entrance lies on the skin or on mucous surface, has enrooted itself. If we do not find this, we doubt about the presence of lues. If we had known better all the atypical appearances, that also a diffuse big and soft oedema could be the primary reaction, we might have decided on the prompt and energetic antiluetic treatment, even when the Wassermann reaction was negative. 
It would be better if physicians, occupied with the throat, would take care to protect their eyes against such disastrous eventualities.

\section{LITERATURE}

ANdRIJA, Spanic.-Zeitschr. $f$. Augenheilk., Vol. XCII.

SIMON.-Zentralbl. f. d. ges. Ophthal., Vol. XV.

Osнiмa.-Zentrabl.f. d. ges. Ophthal., Vol. XXXVI.

Papolczy.-Arch.f. Augenheilk., Vol. CIII.

IGERSheimer. - Syphilis und Auge, 2 Aufl. Berlin: Julius Springer, 1928.

\section{ANNOTATION}

\section{"Recent Advances"}

It was an excellent idea when Messrs. J. \& A. Churchill thought of issuing a series of books on "Recent Advances" in various medical and allied sciences. It was not an altogether original idea, for "Ergebnisse" of physiology and pathology have appeared in German for many years, and admirable "Jahresberichte" of ophthalmology and other branches of science have appeared both in German and English. The latter, however, do not quite fill the same rôle as "Recent Advances." They are concerned only with short abstracts of current literature, whereas "Recent Advances" and "Ergebnisse" select certain well-defined subjects and provide what are to all intents short monographs on these subjects, showing the present state of knowledge-and ignorance. All these publications are invaluable, not only-and especially-to the research worker, but also to those who have to deal more particularly with cognate practical, e.g., clinical, problems. A new series of publications of this kind is now appearing under the title "Documenta" (ophthalmologica, neurologica, gynaecologica, etc.). Of these the first volume of "Documenta Ophthalmologica" is now to hand, and is so excellent as fully to justify the venture. The editorial committee consists of Adler (Philadelphia), Bailliart (Paris), DukeElder (London), Fischer (Utrecht), Ragnar Granit (Helsingfors), Hecht (New York), Heine (Kiel), Magitot (Paris), Wald (Cambridge, Mass., U.S.A.) and Weve (Utrecht). The editor is Prof. A. JuhászSchäffer, of Milan; and the publishers are The Documenta Press, Riedtlistrasse, 19, Zürich 6, and Masson \& Cie, 120, Boulevard St. Germain, Paris (6e).

We cordially welcome this valuable publication, and wish the venture every success. A review of the first volume appears on another page. 